\title{
Low salt diet and frusemide in the treatment of hypertension
}

\author{
C. R. P. GeORGE \\ M.B. B.S., F.R.A.C.P.
}

A. M. BURKE

M.B. B.S.

\begin{abstract}
Department of Renal Medicine, Repatriation General Hospital, Concord, New South Wales
\end{abstract}

\begin{abstract}
Summary
The BPs of 86 of 100 severely hypertensive patients were controlled by measures designed to reduce total body sodium, namely a low salt diet plus the addition of incrementally increased frusemide treatment if diet alone was inadequate. Control of hypertension was maintained over prolonged periods of time in 70 of these patients. Among the 14 who failed to respond adequately, mean plasma renin level was higher (when tested) than in those who did respond adequately, and renal artery stenosis was discovered in 2. Supplementary propranolol controlled the hypertension in 8 of the inadequate responders.
\end{abstract}

\section{Introduction}

The role of sodium reduction in the treatment of hypertension remains controversial (Anon., 1975). That it may have such a role is suggested by clinical observations of hypotension associated with Addison's disease (Spingarn and Hitzig, 1942), by epidemiological identification of lower blood pressures in communities with lower salt consumption (Prior et al., 1968), and by experimental induction of hypertension by saline loading (Coleman and Guyton, 1969). Yet this circumstantial evidence does not prove that acute sodium reduction is of practical value in reducing blood pressure, nor that chronic reduction effectively maintains any control. Despite traditional advocacy of the use of diuretics (Freis, 1974), the results obtained with sodium reduction are quite poorly documented (Kincaid-Smith, 1974). This study was therefore designed to test the acute and chronic effects of a low sodium diet and potent diuretic treatment on the blood pressures and electrolyte status of a series of hypertensive patients.

\section{Patients and methods}

Prospective records which had been maintained on the results of treatment of 100 consecutive unselected patients who had been referred to a specialist clinic for investigation or treatment of hypertension were analysed. Patients were not excluded because they were already in receipt of unsuccessful treatment which had been commenced before referral. However, such treatment was discontinued immediately upon admission to the study. All except 3 patients were admitted to hospital for the period of investigation and initial treatment, and patients were only admitted to the trial if their hypertension was reconfirmed after admission. The patients' details are shown in Table 1. Seventy-five had proved refractory to previous treatments, which included a single anti-hypertensive or diuretic agent in 19 cases, 2 such agents in 32 cases, 3 in 11 cases, 4 in 9 cases, and 5 in 4 cases. The total number of tablets that patients were expected to take was considerable and is shown in Table 1.

Hypertension was defined as a resting supine diastolic blood pressure reading of greater than 100 $\mathrm{mmHg}$ on at least 2 separate occasions. Blood pressures were recorded in the supine position after the patient had been resting for $5 \mathrm{~min}$ and in the erect position after the patient had been standing quietly for $3 \mathrm{~min}$ with the arm held with the cubital fossa at the approximate level of the cardiac apex. The diastolic pressure was read as the Stage 4 Korotkov sound. Appropriate investigations were undertaken in all patients to identify coarctation of the aorta, phaeochromocytoma, Cushing's syndrome and Conn's syndrome. One patient with phaeochromocytoma was identified during the trial period and was excluded from further assessment.

Urinanalysis for protein and sugar, urine culture, excretory urography with rapid sequence early films, fundoscopy, chest X-ray and ECG were performed in all patients. Renal arteriography, micturating cystourethrography, renal biopsy and random urinary $\mathrm{pH}$ measurements were obtained

TABLE 1. Demographic data-mean ( \pm s.d.)

\begin{tabular}{ll}
\hline Sex & 78 male; 22 female \\
Age & $54 \cdot 4(10 \cdot 1$ years) \\
Known duration of & $9 \cdot 2(8 \cdot 3$ years). \\
$\quad$ hypertension & (range 1 week-42 years) \\
$\begin{array}{c}\text { Number of tablets/year } \\
\quad \text { at time of entry }\end{array}$ & $1898(1934)$ (range $0-8760)$
\end{tabular}


in selected patients. Thirty-nine patients had a history or investigations suggesting pre-existing renal disease, 16 gout and 3 diabetes mellitus. All antihypertensive and diuretic treatment was stopped after admission to the trial. In 39 patients a diet containing $100 \mathrm{mimol}$ sodium/day was then provided for 3 to 7 days at which time their plasma renin activities were measured in both supine and erect positions using the method of Haber et al. (1969).

All patients were then started on a diet containing only $50 \mathrm{mmol}$ sodium but otherwise of normal composition. If the resting supine diastolic blood pressure remained above $100 \mathrm{mmHg}$ for 3 days, frusemide was commenced at an initial dose of 40 $\mathrm{mg}$ daily. The dose of frusemide was increased every third day by doubling the previous dosage if the resting supine diastolic blood pressure remained above $100 \mathrm{mmHg}$ or until symptomatic postural hypotension occurred. The maximum dose of frusemide was $750 \mathrm{mg} /$ day in patients with initially normal renal function or $2 \mathrm{~g}$ /day in those with reduced renal function. In those patients who reached the maximum dose of frusemide and whose urinary sodium was confirmed to be less than $50 \mathrm{mmol} / 24 \mathrm{hr}$ (implying that the diet was being adhered to) the patient was considered as being inadequately responsive to sodium reduction, and propranolol $40 \mathrm{mg}$ twice daily was added and increased incrementally until the resting supine diastolic BP fell below $100 \mathrm{mmHg}$ or a dose of $640 \mathrm{mg}$ daily was reached.

Biochemistry was measured on a Technicon AutoAnalyzer and haematology on a Coulter Counter. The body weight of in-patients was recorded daily, and of out-patients at each visit. Twelve patients obtained sphygmomanometers and scales to record their BP and weight at home. Potassium supplements were administered if the serum potassium level fell below $3 \mathrm{mmol} / \mathrm{l}$, and allopurinol if the serum urate rose above $600 \mu \mathrm{mol} / 1$.

Statistics were evaluated using the paired $t$-test.
Results

The BP of 86 patients responded adequately to low salt diets plus diuretic treatment, following discontinuation of other anti-hypertensive medications. Seventeen of these responded to low salt diet alone with falls in BP from mean levels of $183 / 109 \mathrm{mmHg}$ supine and $181 / 112 \mathrm{mmHg}$ erect to $147 / 89 \mathrm{mmHg}$ supine and $145 / 89 \mathrm{mmHg}$ erect. The other 69 patients achieved eventual adequate control of BP by low salt diet and frusemide. Incremental increases in frusemide dosage short of the increase which eventually controlled the hypertension were not necessarily accompanied by incremental falls in blood pressure. In the 86 who did ultimately respond adequately there was a mean (and highly statistically significant) reduction in body weight of $3.9 \mathrm{~kg}$ (Table 2), corresponding to an equally significant fall in systolic and diastolic BP, whether measured in the supine or erect positions.

During the follow-up periods of up to one year (mean 18 weeks) the weight reduction was maintained (mean reduction $4.2 \mathrm{~kg}$ ) as was excellent control of BP (resting supine diastolic BP $100 \mathrm{mmHg}$ or less) in 70 patients, including 12 receiving low salt diet alone. In some of those in whom control was lost during the follow-up period, failure to adhere to the low salt diet was admitted and in others suspected because of the detection of a urinary sodium excretion of greater than $50 \mathrm{mmol} / \mathrm{day}$. The mean number of tablets being consumed fell from 1672/ year on admission to 803/year after treatment. Potassium supplements were required in the acute phase by one patient and in the chronic phase, by 9 , to maintain serum potassium above a level of 3 $\mathrm{mmol} / \mathrm{l}$. Nineteen patients required allopurinol in the acute phase and 28 in the chronic phase to maintain the serum urate level below $600 \mu \mathrm{mol} / 1$.

In the 14 patients who failed to respond adequately to sodium reduction, there was an even greater fall in body weight $(4.6 \mathrm{~kg})$. All BPs fell by statistically significant amounts, but in no patient did it fall to a

TABLE 2. Responses of weight and blood pressure to treatment-mean ( \pm 1 s.d.)

\begin{tabular}{|c|c|c|c|c|c|c|}
\hline & \multicolumn{3}{|c|}{ Responders (86 patients) } & \multicolumn{3}{|c|}{ Inadequate responders (14 patients) } \\
\hline & Admission & $\begin{array}{r}\text { Sodium } \\
\text { deplete }\end{array}$ & Latest & Admission & $\begin{array}{c}\text { Sodium } \\
\text { deplete }\end{array}$ & Latest \\
\hline Weight (kg) & $80 \cdot 5(15 \cdot 4)$ & $76 \cdot 6(14 \cdot 2)^{*}$ & $76 \cdot 3(13 \cdot 8) \dagger$ & $75 \cdot 6(15 \cdot 8)$ & $71 \cdot 0(16 \cdot 3)^{*}$ & $74 \cdot 7(18 \cdot 7) \ddagger$ \\
\hline $\begin{array}{l}\text { Supine BP } \\
\text { Systolic } \\
\text { Diastolic }\end{array}$ & $\begin{array}{l}191(27) \\
120(15)\end{array}$ & $\begin{array}{l}146(18)^{*} \\
91(8)^{*}\end{array}$ & $\begin{array}{r}157(23) \dagger \\
97(11) \dagger\end{array}$ & $\begin{array}{l}211(25) \\
121(16)\end{array}$ & $\begin{array}{l}172(32)^{*} \\
115(11)\end{array}$ & $\begin{array}{l}168(25)^{*} \\
104(19) \dagger\end{array}$ \\
\hline $\begin{array}{c}\text { Erect BP } \\
\text { Systolic } \\
\text { Diastolic }\end{array}$ & $\begin{array}{l}184(22) \\
117(15)\end{array}$ & $\begin{array}{r}133(23)^{*} \\
89(10)^{*}\end{array}$ & $\begin{array}{r}148(2) \dagger \\
95(13) \dagger\end{array}$ & $\begin{array}{l}211(25) \\
123(14)\end{array}$ & $\begin{array}{l}151(28)^{*} \\
102(32) \ddagger\end{array}$ & $\begin{array}{r}151(33)^{*} \\
90(33) \dagger\end{array}$ \\
\hline Tablets/day & $4 \cdot 5(4 \cdot 8)$ & $2 \cdot 1(2 \cdot 1)^{*}$ & $2 \cdot 2(2 \cdot 7) \ddagger$ & $4 \cdot 5(4 \cdot 8)$ & $2 \cdot 7(2 \cdot 3) \dagger$ & $2 \cdot 2(7 \cdot 7) \dagger$ \\
\hline $\begin{array}{l}\text { Frusemide } \\
\text { mg/day }\end{array}$ & & $286(237)$ & $245(205)$ & & $488(236)$ & $410(215)$ \\
\hline
\end{tabular}

* $P<0.0005, \dagger P<0.01, \ddagger P<0.05$ compared with admission figure. 
resting supine diastolic BP of $100 \mathrm{mmHg}$ or less. Following addition of propranolol, body weights returned towards those on admission (mean $0.9 \mathrm{~kg}$ less than on admission) and the BP was adequately controlled in 8 of the 14 patients. This control was maintained during the follow-up periods of up to 10 months (mean 17 weeks). In a further 2 patients, tight renal artery stenosis was identified (one responded to unilateral nephrectomy and a $50 \mathrm{mEq}$ sodium diet; the other, with bilateral renal artery stenosis, was judged unfit for operation and his BP remains uncontrolled). In a further patient, BP was always well controlled when she or her husband recorded it at home, but was always elevated when measured by a medical practitioner or by the patient or her husband at the hospital, despite the demonstration that both the patient and her husband were accurate when recording the pressures of other people. Two further patients, who remained uncontrolled, volunteered that they did not take their medications or diet, and this was suspected in a third patient.

There was a small, but statistically significant, fall in the serum sodium level in both groups in the acute stage (Table 3), but this returned towards baseline values with chronic therapy. In the group which responded adequately to sodium reduction, the blood sugar level rose in the acute stage, but fell again with chronic therapy. Statistically highly significant falls in the serum potassium, chloride and phosphate levels; and rises in the bicarbonate, urea, creatinine, albumin, calcium and urate levels occurred in both the acute and chronic treatments of both groups. There were no statistically significant changes in the serum cholesterol or haematocrit values in the responders, but in the group which failed to respond adequately to sodium reduction, the cholesterol rose mildly.

The mean plasma renin activity (on no treatment except a $100 \mathrm{mmol}$ sodium diet) in the 32 patients tested in the group which later responded adequately to sodium reduction was $0.9 \pm 0.8 \mathrm{ng} / \mathrm{ml} / \mathrm{hr}$ in the supine position and $1.9 \pm 1.7 \mathrm{ng} / \mathrm{ml} / \mathrm{hr}$ in the erect position. In the 7 patients tested from the group which later failed to respond adequately, it was $3 \cdot 8 \pm 5.7$ and $5 \cdot 7 \pm 7 \cdot 1 \mathrm{ng} / \mathrm{ml} / \mathrm{hr}$ in these 2 positions respectively.

Thirty of the responding group and 5 of the inadequately responding group had serum creatinine levels of greater than $130 \mu \mathrm{mol} / 1$ on admission. In the 65 patients with serum creatinine levels of $130 \mu \mathrm{mol} / \mathrm{l}$ or less, the mean admission BP was $190 / 117 \mathrm{mmHg}$ supine and $185 / 116 \mathrm{mmHg}$ erect. The mean serum creatinine level was 106 $\mu \mathrm{mol} / 1$. Corresponding figures after sodium reduction were $150 / 95 \mathrm{mmHg}, 139 / 93 \mathrm{mmHg}$ and $124 \mu \mathrm{mol} / \mathrm{g}$ respectively. In the 35 with admission serum creatinine levels of $>130 \mu \mathrm{mol} / \mathrm{l}$, the mean adso

TABLE 3. Responses of haematology and biochemistry to treatment-mean ( \pm 1 s.d.)

\begin{tabular}{|c|c|c|c|c|c|c|}
\hline & \multicolumn{3}{|c|}{ Responders (85 patients) } & \multicolumn{3}{|c|}{ Inadequate responders (14 patients) } \\
\hline & Admission & $\begin{array}{l}\text { Sodium } \\
\text { deplete }\end{array}$ & Latest & Admission & $\begin{array}{l}\text { Sodium } \\
\text { deplete }\end{array}$ & Latest \\
\hline $\begin{array}{l}\text { Haematocrit } \\
\text { Sodium }\end{array}$ & $41(6)$ & $41(7)$ & $41(5)$ & $41(6)$ & $45(8)$ & $42(3)$ \\
\hline $\begin{array}{r}(\mathrm{mEq} / \mathrm{l}) \\
\text { Potassium }\end{array}$ & $142(4)$ & $140(4) \ddagger$ & $141(3)$ & $142(4)$ & $138(2) \dagger$ & $141(4)$ \\
\hline $\begin{array}{l}\text { (mEq/l) } \\
\text { Chloride }\end{array}$ & $4 \cdot 4(0 \cdot 6)$ & $3.8(0 \cdot 78)^{*}$ & $4 \cdot 1(0 \cdot 6)^{*}$ & $3.9(0.8)$ & $3 \cdot 5(0 \cdot 7) \ddagger$ & $4 \cdot 0(0 \cdot 6)$ \\
\hline $\begin{array}{c}(\mathrm{mEq} / \mathrm{l}) \\
\text { Carbonate }\end{array}$ & $104(6)$ & $95(7)^{*}$ & $99(5)^{*}$ & $102(3)$ & $91(6)^{*}$ & $97(6) \ddagger$ \\
\hline $\begin{array}{l}(\mathrm{mEq} / \mathrm{l}) \\
\text { Urea }\end{array}$ & $28(4)$ & $32(6)^{*}$ & $29(6) \dagger$ & $28(4)^{*}$ & $34(5)^{*}$ & $31(3) \ddagger$ \\
\hline $\begin{array}{c}(\mathrm{mg} / \mathrm{dl}) \\
\text { Creatinine }\end{array}$ & $58(35)$ & $94(71)^{*}$ & $73(57)^{*}$ & $51(32)$ & $91(52)^{*}$ & $72(47) \ddagger$ \\
\hline & $2 \cdot 0(1 \cdot 5)$ & $2 \cdot 6(2 \cdot 1)^{*}$ & $2 \cdot 5(2 \cdot 2) \dagger$ & $2 \cdot 1(1 \cdot 7)$ & $2 \cdot 4(2 \cdot 2) \ddagger$ & $2 \cdot 6(2 \cdot 8)$ \\
\hline $\begin{array}{l}\text { (mg/dl) } \\
\text { Albumin }\end{array}$ & $134(41)$ & $144(44) \ddagger$ & $135(65)$ & $133(23)$ & $161(61)$ & $156(86)$ \\
\hline $\begin{array}{c}(\mathrm{g} / \mathrm{dl}) \\
\text { Calcium }\end{array}$ & $4 \cdot 7(0 \cdot 7)$ & $5 \cdot 0(0 \cdot 5)^{*}$ & $5 \cdot 2(0 \cdot 5)^{*}$ & $4 \cdot 7(0 \cdot 3)$ & $5.0(0.4) \dagger$ & $5 \cdot 2(0 \cdot 6)$ \\
\hline $\begin{array}{c}(\mathrm{mg} / \mathrm{dl}) \\
\text { Phosphate }\end{array}$ & $9 \cdot 6(0.6)$ & $9.9(0 \cdot 8)^{*}$ & $9 \cdot 7(0 \cdot 6) \ddagger$ & $9.6(0.4)$ & $10.2(0.4) \dagger$ & $10.0(0.5) \ddagger$ \\
\hline $\begin{array}{c}(\mathrm{mg} / \mathrm{dl}) \\
\text { Cholesterol }\end{array}$ & $3 \cdot 7(1 \cdot 3)$ & $3 \cdot 3(0 \cdot 7) \dagger$ & $3.6(1.0) \dagger$ & $3 \cdot 1(0 \cdot 5)$ & $3.4(0.4)$ & $4.0(0.5)$ \\
\hline $\begin{array}{r}(\mathrm{mg} / \mathrm{dl}) \\
\text { Uric acid }\end{array}$ & $268(87)$ & $257(65)$ & $268(60)$ & $251(45)$ & $266(52) \ddagger$ & $279(54)$ \\
\hline$(\mathrm{mg} / \mathrm{dl})$ & $7 \cdot 5(2 \cdot 0)$ & $9 \cdot 1(2 \cdot 7)^{*}$ & $8 \cdot 0(2 \cdot 2) \ddagger$ & $7 \cdot 5(1 \cdot 6)$ & $9 \cdot 5(2 \cdot 1) \dagger$ & $8 \cdot 6(2 \cdot 2)$ \\
\hline
\end{tabular}

* $P<0.0005, \dagger P<0.01, \ddagger P<0.05$ compared with admission figure. 
mission BP was $200 / 125 \mathrm{mmHg}$ supine and $193 / 122 \mathrm{mmHg}$ erect, with a mean serum creatinine level of $300 \mu \mathrm{mol} / \mathrm{l}$. Corresponding figures after sodium reduction were $145 / 92 \mathrm{mmHg}, 130 / 90$ $\mathrm{mmHg}$ and $371 \mu \mathrm{mol} / 1$ respectively. Fifteen of the responding group had evidence of ischaemic heart disease before admission to the trial and a further 5 had had cerebrovascular accidents. Two of this group suffered myocardial infarctions during the trial period and a further one died suddenly 3 months after entry into the trial. Four of the nonresponding group had pre-existing evidence of ischaemic heart disease and a further 2 had had cerebrovascular accidents. One of this group died suddenly 8 months after entry into the trial.

\section{Discussion}

Despite a debate of 70 years' duration, sodium reduction remains an enigmatic component of antihypertensive therapy (Anon., 1975; Ambard and Beaujeard, 1904). Kincaid-Smith et al. (1975) suggest they are 'unable to find evidence that mild to moderate restriction of sodium intake is beneficial in the control of hypertension', and that it is 'very dangerous in patients with impaired renal function'; Carney et al. (1975) claim that 'the more a patient was depleted of sodium, the lower was the blood pressure'. The present study was therefore undertaken in an attempt to determine whether the control of hypertension could be achieved merely by use of low salt diet and diuretic treatment in unselected patients presenting with hypertension.

The results demonstrate that $86 \%$ of hypertensive patients when treated with a low salt diet and frusemide in sufficient dosage reduced their diastolic BPs to below $100 \mathrm{mmHg}$. This treatment was accompanied by an acute mean fall of $4.8 \%$ $(3.9 \mathrm{~kg})$ in body weight, and changes in serum biochemistry which suggested an accompanying net loss of slightly hypertonic saline. There was also a loss from the blood of potassium and hydrogen ions, but an accumulation of uraemic toxins, glucose and uric acid. These biochemical changes are recognized complications of diuretic therapy (Laragh, Heinemann and Demartini, 1958).

The present study also shows that in $70 \%$ of hypertensives the adequate response can be maintained indefinitely whilst a near normal life is being pursued. As a subsidiary benefit of such treatment, the patient need take only half as many tablets per day as would be necessary with some alternative therapeutic regimens, despite far superior blood pressure control. Achievement of such results is almost certainly enhanced by instruction of patients that increased salt intake will increase BP, increased diuretic intake reduce it, and that if the patient weighs himself and records his BP each day he can usually adjust his salt intake and diuretic dose to control his hypertension.

The results are consistent with the concept of Guyton et al. (1972) that ambient blood pressure levels are determined principally by the ability of the kidneys to excrete sodium, as modified by various subsidiary mechanisms. They also suggest, but do not prove, that many hypertensive people may live in a state of relative sodium excess. Proof of such a hypothesis would require demonstration of increased total body sodium levels in hypertensives. Unfortunately, divergent results have been obtained in various studies of plasma volume and exchangeable sodium in such patients (Ross, 1956; Tarazi, Frohlich and Dustan, 1968) and these levels may not be accurate indicators of total body sodium. Future application to hypertensive patients of methods for determining total body sodium may resolve this question.

That not all hypertensive patients can be controlled adequately by sodium reduction is demonstrated by the $14 \%$ whose diastolic BPs are not reduced below $100 \mathrm{mmHg}$ except with the development of significant postural hypotension, i.e. except with presumed excessive saline depletion. Nevertheless, even these patients do sustain a significant reduction in pressure on low salt diets and diuretic treatment. No diagnostic features accurately separate the 2 groups, although the mean plasma renin levels of the inadequate responders tend to be higher, albeit with considerable overlap. Large vessel renal artery stenosis was found radiologically in 2 of the 14 inadequate responders, but was not demonstrable in the others. The incidence of impaired renal function, as evidenced by elevated serum creatinine levels, was approximately equal at about one third of each group. When sodium reduction was supplemented by $\beta$-adrenergic receptor blockade, the hypertension was controlled in approximately $50 \%$ of the initially inadequately responding patients, and it is possible that this figure was artificially low owing to some patients failing to adhere to prescribed regimens. Ultimately, the particular feature which rendered this group incompletely responsive remained unidentified.

Treatment with combined restriction of sodium intake and a large diuretic dosage is not innocuous. Asymptomatic side effects occurred in most patients. These included hypokalaemia, hyperuricaemia and alkalosis in some, and a mild elevation in serum urea and creatinine in many. Two patients with severe pre-existing renal failure became so azotaemic that commencement on maintenance dialysis was considered desirable, although it is of interest that in 5 others this did not occur. While it is possible that the underlying disease had progressed independently in the 2 , sodium depletion cannot be excluded as the 
proximate cause. Nevertheless, assuming the presence of adequate dialysis facilities, the patient with end-stage renal failure is at greater risk from uncontrolled hypertension than from a further minor loss of renal function, even though this may precipitate the commencement of dialysis. For the patient with milder renal failure, numerical rises in serum urea and creatinine levels are of even less practical significance and are a small price to pay for adequate control of BP. Because of the patients' ages and the duration and severity of their hypertension, the significance of 2 cases of myocardial infarction and 2 sudden deaths during the trial period cannot be assessed in the absence of an untreated control group.

In conclusion, therefore, it appears that low salt diet and diuretic therapy will adequately lower the BP of most hypertensive patients regardless of its severity. However, this treatment is inadequately effective in $14 \%$. Although it is often associated with side effects, those definitely produced by it are usually asymptomatic and readily reversed.

\section{Acknowledgments}

The assistance of the many practitioners who referred patients, of the resident medical staff who helped care for them, and of Dr Gordon Stokes at Sydney Hospital for performing plasma renin assays, is gratefully acknowledged.

\section{References}

Ambard, L. \& Beaujeard, E. (1904) Archives générales de médecine, 1, 520.

ANON (1975) Salt and hypertension. Lancet, i, 1325.
Carney, S., Morgan, T., Wilson, M., Matthews, G. \& RoBerTS, R. (1975) Sodium restriction and thiazide diuretics in the treatment of hypertension. Medical Journal of Australia, 1, 803.

Coleman, T.G. \& Guyton, A.C. (1969) Hypertension caused by salt loading in the dog. Circulation Research, 25, 153.

FREIS, E.D. (1974) The treatment of hypertension. In: Hypertension Manual (Ed. by Laragh, J.H.), p. 743. Yorke Medical Books, New York.

Guyton, A.C., Coleman, T.T., Cowley, A.W., Scheel, K.W., Manning, R.D. \& Norman, R.A. (1972) Arterial pressure regulation and overriding dominance of the kidneys in long-term regulation and in hypertension. American Journal of Medicine, 5, 584.

Haber, E., Koerner, T., Page, L.B., Kliman, B. \& Purnode, A. (1969) Application of radioimmunoassay for angiotensin I to the physiologic measurements of plasma renin activity in normal human subjects. Journal of Clinical Endocrinology, 29, 1349.

KinCAID-Smith, P. (1974) Management of severe hypertension. In: Hypertension Manual (Ed. by Laragh, J.H.), p. 787. Yorke Medical Books, New York.

Kincaid-Smith, P., MacDonald, I.M., Hue, A., Lever, M.C. \& FANG, P. (1975) Changing concepts in the management of hypertension. Medical Journal of Australia, 1, 327.

Laragh, J.H., HeinemanN, Ho.O. \& Demartini, F.E. (1958) Effect of chlorothiazide on electrolyte transport in man. Journal of the American Medical Association, 166, 145.

Prior, I.A.M., Evans, J.C.G., Harvey, H.P.B., Davidson, F. \& LindSEY, M. (1968) Sodium intake and blood pressure in two Polynesian populations. New England Journal of Medicine, 279, 515.

Ross, E.J. (1956) Total exchangeable sodium in hypertensive? patients. Clinical Science, 15, 81.

SPINGaRN, C.L. \& Hitzig, W.M. (1942) Orthostatic circulatory insufficiency. Archives internationales de médicine, 69 23.

Tarazi, R.C., Frohlich, E.D. \& Dustan, H.P. (1968) Plasma volume in men with essential hypertension. New England Journal of Medicine, 278, 762. 